\title{
自閉症児の教育診断に関する一考察
}

\author{
村 田 保 太 郎 \\ （渋谷区教育研究所）
}

\section{I 序論}

小児自閉症をめぐり、その概念・病理・中心的症例の 符疇等の論争は、今日もなお続いている。しかし、立場 を異にするそれぞれの医療機関で小児自閉症と診断され た児童は、次々と各地の小・中学校汇就学している現状 にある。そして、その数は漱次增加している現状であ る。

そのような状態の中で自閉症児に学校への就学を推進 したのは、小児自閉症を診断して投薬とベッドを与兄る だけに終っていた医師ではなく、長期にわたって自閉症 児に樣々な治療教育的な方法を試及、自閉症児の中に秘 められていた教育の可能性を見出した治療教育者たちで あった。更に、受け入れ側の小学校教師との閒に深い共 通理解が可能となる上らに努力を続けてきた治療教育者 が、自閉症児の就学を可能にしたのである。

一方、自閉症児を受恃った担任教師の苦悩と努力む また、容易なものではなかった。それが結集されて、東 京都情緒障害児研究会（都情研）や、全国情緒障害研究 会 (全情研) が結成され、自閉症児の学校適応を可能に した事例が次々と報告され、その条件が確立しつつもる のである。

このように、小睍自閉症をめぐる論争とかけはなれた ところで学校教育の現場の実践が効果をあげつつあるこ とは、注目してょい事実である。

自閉症児の状態像が好転するという経過が明らかにさ れ、就学児童が增加与るにつれて、教育の場にある者が それらの児童の教育診断を積極的、主体的に実現してい くことは、必然的なことである。

それは自閉症児の就学問題洛力を重秝てきた治療教 育者と共通した意識の中でこそ行い得るものであって、 今後汇招いても治療教育者と教育者との提携を必要とす ることを意味し、今後の治療教育を推進する基盤ともな るものである。

自閉症児の教育診断に関与る研究の目的は、自閉症児 を报う教育現場での診断を、より明確なものにするため の一つの試みである。ここに、我々が行った試みについ て述べ、ご批判を得たいと考えている。

\section{II 自閉症児の就学問題に関する研究}

自閉症児の就学問題に関しては、既化第 8 回の日本児 童精神医学会総会に招いて発表したが、ここにその結果 のみを列举して、教育診断への基盤としたい。

（1）東京都湉いては、自閉症児の就学件数は年々増 加している。昭和 42 年度は 52 名、昭和 43 年度は 78 名 (都情研調查)である。

(2) 特殊学級隹入級する者より、普通学級化就学する 者が多くなってきている。

（3）学年の上昇に伴い疎通性が増し、担任の負担も軽 くなり、学校適応の可能性を增している。それが顕 著な時期法、小学校 3 年生〜 4 年生頃である。

(4) 1 年間の就学猶予を経て入学した自閉症胃の方が 猶予をしないで入学した子どもよりも、就学後の適 㐫状態が好転している例が多い。

(5) 自閉症児に学校不適応の状態の好転への変化が表 われるのは、入学後 6 ケ月以内であることが多い。

(6) 自閉症児を受け入れる体制の良い学校にあって は、特に適応状態が好転する場合の変化が大きく、 学校適応を可能にする率が高い。

(7) 自閉症児の教育には教師との良い出合いに加觉て 学校全体の良い受け入れ体制が重要である。

(8) 自閉性の程度には差があるが、それらは蹯通性に 関し連続性を示し、子ぞも自身の発達と治療教育の 努力により、疎通性への変化が期待される。

（9）自閉性を人間の本質の中でとらえ、普通児との交 流に上る集団の力動性の中で、価値学る一個の人格 として位置づけることにより、状態像の改善は促進 される。

\section{III 自閉症児の教育診断に関する問題点}

\section{1. 教育診断の要素}

教育診断は、次の 3 つの要素から成立している。

(1) 自閉症児の就学判定

(2) 自閉症児の就学措置及び制度・財政・管理体 制の確立

(3) 自閉症児の教育評価

この 3 つの要素は相互に関連し合うものであり、単独 
には存在し得ないものである。例えば、施設・設備・人 的構成等受け入れの能力がないのに就学判定のみが先行 するのならば、いたずらに览童を類別するのみで、自閉 症児を治療や教育の場から楴め出すことになり、また、 障害の程度や質に応じた教育方法諭を持たずに、教育措 置のみが先行してしま学ば、教育効果は上がらず、混乱 のみが残ることは明白である。

2. 自閉症児の特質と教育診断

(1) 知能と自閉性との関連

これは、自閉症の中心的症例とは何かといら自閉 症の本質的な問題にかかわる問題であるが、われわ れは、知能測定の結果がそのまま自閉症览の知的能 力の程度を示すことにはならないという経験を多く 持っている。

自閉症児に鈴木 Binet やWSIC 等の知能検査を 実施した結果は、測定不能の者が多く、測定が可能 であってもボーダーラインか又はそれ以下のむのが 多かった。特に就学時の健康診断の際の知能検查で は、大部分が得点が低く、再検査実施のたに相談所 等に备わされていた。

W I S Cを実施することのできた症例では言語性 I $Q$ 上り、動作性 I $Q$ が高く、しか子、各下位検査 の得点はバラッキが大きかった。

自関症児の知的構造の特性を示す例を学げてみよ 5。

$\mathrm{A}$ 児 ( 5 年生、11才) に鈴木 Binet 知能検查を実 施した結果を述べると、6才児相当の了解問題（も しも、あなたの家が火事で然えているのを見つけた ら）＜24問>とか、（もしあなたが何か人の物をこ わした時は）（26問>等や、用途以上の定義を求め る問題 <35問 $>$ に対しては、長時間考え込み、時 には「わかりません。」と困惑した表情で答えるか と思えると思 5 と、<68問>の 8 数字の反唱（19才 相当）とが、<75問（22才相当の難かしい推理問題 に対して明確に答えたりした。

A 児の知能指数を求めてみると、58であったが、 I Qで示すことができ妨どバラッキが大きい。つ まり、解らないのではなく、質問を論理的に、むず かしく考えてしまうので、どう答えて良いのかわか らないために、「わからない」と答えてしまうので ある。例えば、（家が火事で然えているのを見つけ たら）という時に「わかりません。」という答えを したが、「何がわからないのですか。」というと、 「実際にそのようなことが起きるかどらかわからな
いし、もし本当に然えているのを見つけても、自分 がその時になってみなければ、どらするかわからな い。」といらのである。「それでは、もしそらなった ら君はどうすると思いますか。どうしなければなり ませんか。」重祖て質問すると、長いこと考えて いて、「119番に電話する。近所の人に知らせる。 小さいらちなら水で消す。大事な物を運んだりしま す」。答える。しかし、正規の instruction では、 発問の形式は一切变更してはならないので、彼の回 答は得点にはならないのである。

このような例は用途によって定義したり、用途以 上の優秀な定義 (18問・35問)にもみられ、またW I S Cの単語問題にもみられた。「机とは何ですか」 「どんな物ですかいってごらんなさい。」とか、学 校とはどんなるのですか。」「噴火とは何ですか。」 の問いに対しても、それだけでは彼にとってどのよ らに答えて良いのかわからないのでさる。

instruction は「も5少し説明してください。」と いうように中性的な（非誘導的また性非暗示的）も のに限定するよ5になっている。この場合も、その ものの用途、形状、状熊、原因、材質、機能、構造、 また、その結果等について、一つ一つを分けて聞く ときちんとしかも詳細に答えるのである。

A児に対しては、このように instructionをか兄 て、もう一度テストをやり直してみると、初めの I Q 58 は、I Q 128 に上年した。

その他、検查者との蹯通性に欠けるために、知能 検查の結果、精薄と診断されて、精薄特殊学級を勧 奖されている例は非常に多い。特に就学時の知能検 查では、現在ほとんどの学校で標準化された団体知 能検查を採用しているが、自閉症児がこの検査で正 常児の範囲内の得点をする例は極めて少ない。

何をもって知的能力といらかの論議は今後取り組 むべき研究課題であるが、自閉症巟の中には秘めら れた知的能力があり、社会適応 (疎通性) が增して くると、それが現れて、学校での知的学習について 行くこともできるし、良い成績をあげる例もあるこ とをじゅうぶんに認識した上で、就学判定にのぞむ 必要がある。

（2）自己中心性と自閉症との鑑別

いわゆる「わがままな子」は本人にとって圧力と なる相手との力関係でその程度が異ってくる。即 ち、その関係の中に䠅通性を認めることができる が、自閉症児の一見わがままと見られやすい行動に 
は、その対象となる力関係とは全く別の動因、いら なれば内的適応を求めての要求が満たされるまで相 手のない「わがまま」な行動は継続されるのであ る。すなわち、そこには疎通性を全く感じさせない ものがある。教育評価の際にしばしば自閉症巟を誤 解するのは、この点である。

親に対して、「甘やかしている」「過保護である」 「躾が行き届いていない」等の指摘を与えて、注意 を促す教師もあるが、自閉症児の親に対する指導と しては、誤っている。

また、両親との面接において、自閉症児の親が非 常に論理的な話し方をすると、原因を親の冷淡さや 拒否的態度に結びつけてしまうことがある。確かに 或る親は、「いつも敃世話になりまして。」「扮寒く なりました。」「この頃子どもはどんな具合でしょ

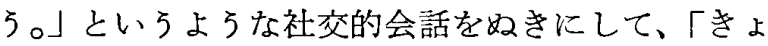
らは、この点とこの点にいって………」と話し始 める場合がある。小児自閉症の発生原因を心因論に 結びつける䛊解はここから出てくる。このことは就 学後の扱い方に大きな影響を及ぼす点である。

（3）予測性とカリキュラムとの関連

普通児の教育に招いては、指導や訓練の積み重敉 が進歩と発達の基盤になる。従って、指導目標をた て、そこに到達するための方法や手段、技術を段階 的に構成することができる。即ち、カリキュラムは 教育効果の予測性によって構成されているのであ る。

しかし、自閉症児は、彼自身が興味と関心を示し た対象でないと、指導上の指示や教示を全く受けつ けないことがある。それに反して、興味を持った対 象に対しては、䉆くべき集中力を示し、同年令水準 をはるかに越す能力を発揮したというェピソードは 枚挙に限りがない。

また、彼等には独特の論理性があり、指導者の指 示がその思考過程の中で明確に把握された時には、 思わ行動の变化を示し、突如として状態像が好転 した例もみられる。

例えば、治療機関の観察の結果、とても就学は無 理であろらといわれた自閉症児が入学してみると、 旬日を待たずして学級集団に適応したといらことも あった。われわれの調査によっても、小学校 $3 \sim 4$ 年生になると学校適灾がり、担任教師がそれ程の萿 労なく报える状態に好転する症例が多いことがわか った。
自閉症児は恒常的な障害でなく教育による効果が 期待できるものである、しかも多くの症例桠通児 との力動的な交流の経験を通じて好転するという面 を見逃すことはできない。自閉症児は就学期前後の $5 \sim 6$ 才には、状態像の悪い者が多く、特に 6 才と いう時点で就学時健康診断のためテストを受けるの で、結果はしばしば悪くでる。従って就学を拒否さ れたり、特殊学級を勧奖されることが少くなかっ た。従って、 $1 \sim 2$ 年の就学猶予の後に、普通学級 に入れるかまたは普通児との交流が可能な治療学級 を置いて、この時期の治療教育を行ならことは、非 常に重要なことであり、早急に解決すべき問題であ る。

IV 教育評価の基準と就学判別の基準の試み

自閉症児に対する教育評価の基準をいかに立てる か、就学判別の基準をいかに立てるかは、自閉症児の 学校適応上の問題を解決する上で極めて重要である。 そこでこの点を明らかにする手始めとして次の調査を 行った。

(1) 研究方法

東京都内の学校に在籍している自閉症児の担任教 師72名に対し、質問紙によって回答を求め、この資 料をもとにして検討をすすめた。な报、担任とのイ ンタービュー及び研究協議会での記録を併用した。

(2) 調查対象

対象となった教師72名の5ち50名から回答があっ た。回収率は $73 \%$ であった。実施は昭和 43 年 7 月 1 日である。

(3) 質問紙

7 項目を中心として、更に70項目にわたる質問項 目を作製した。

1. 就学決定までの経路、手続き

自閉症の猃断に関すること、治療経 過 就学猶 予、就学決定 …….. etc.

2. 学校体制の状況

担任決定、性別、教職経験、校内の協力態勢、 意識 …….. etc.

3. 対保護者との関連

自閉症児に対する態度、問題点、理解を得るた めの方策、啓蒙 ……. etc.

4. 対览童との関連

自閉症児に対する態度、問題点、どのように働 きかけたか ……... etc.

5. 担任との関連及び適応状況 
本児をどう受けとめているか、感じ力扱い力、 集団、学習、生活習慣、対人関係、知的能力、 特異な行動、好転への変化の内容、時期、恶い 変化、言語、困難点 ……... etc.

6. 子どもに対する保護者の養育態度

7. 自閉症児の教育

就学したことの可否、教育措置、其体的配慮、 指導方針、今後の問題

以上であり、他の自閉症児の適応状況々客観的に比 較検討でききるような努力をした。

70項目の5ち52項目は選択肢法で、残り18項目は記述 式を用いた。

つぎに総合観察表 (Table 1) を用いて評価してもらっ た。これは 50 名の回答者に配布し、39名の回収を得た。 回収率は $78 \%$ であり、教育評洒基準之就学判別差準を作 成する試みをした。

適応状況を把握するために70項目にわたる調査項目を たてたが、担任教師が、子どもの全般的な状態から適応 しているかどうかを評価すると、必ずしも各項目ごとの 状沉と全体像は一致しなかった。例光ば、A担任は、調 查項目各々については低く評価しているのに全般的な子 ぞもの状態は適応していると回答している。B担任は、 各々の項目では高く評価しているのに、全体としては適 応していないと諑価している。これは、教育という機能 が教師を媒介として行なわれている以上、どうしても担 任教師の意識や見解、そして人格が投影されて、子ぞも を評価する面がでてくるからである。

この点では、後述するよりに、「就学したことは良か ったかどらか。」「指導の難易度。」「指導の效果。」「今 後の予測。」などの項目にも同様の傾向が見られた。こ れらの相違点を解決するためには、経験を持ら訓練され た観察者数名による長期観察を行ない、一致度を高めて いく方法を用いる必要がある。今回は単純な統計的処理 によったが、今後は、長期観察による方法を用いたいと 考えている。

(4) 総合観察表 - Table $1-$

各項目は、自閉症児の状態像を把握する観点に立 って作製されているが、特学校適応という観点に 立って項目を作った。自閉症児の状態像を把握する には、もちろ九、多くの観点があるが、今回は学 校に就学し、学校生活を送るという点からみて、次 の3つに大別した。

1. 自閉性の程度（自閉性から疎通性末での連続性 の中で観察する)
2. 知的能力の程度 (言語能力も含む)

3. 発達の程度 （予测性もみていく）

これらの観点に、担任の観察の結果が現れるょうに項 目を設定した。しかし、担任個人の主観的な評洒となっ たきらいがある。

その内容は一 Table 1 一に示したものである。

前述の学校適応の状態については、具体的な場面 (70 項目)でとらものであり、これと総合観察表の評価 と比較すると一致度は高かった。

例えば

(29) 消掃

$$
\begin{aligned}
& \text { アいつもする } \\
& \text { イすることが多い } \\
& \text { ウする時としない時がある } \\
& \text { エない時が多い } \\
& \text { オ いつもしない }
\end{aligned}
$$

で（エ）に記入したものは、総合観察表の（2）集 団参加では（3）の段階につけていた。

総合観察表の4段階評何はつぎの基準によった。

評価（1）普通巟を想定し、普通学級で十分に適応 できるもの

評洒 (2) 普通学級ではトラブルの多い状態をあげ

評価 (3) $\}$ た。相対的に 1 と 2 に評価した項目が多 ければ普通学級で適応する可能性が大き く、3が多くなれば盖通学級では間題が 多く、特别学級を考慮しなければならな い状態にむる。

評価 (4) 教育の場では適応困難が予想され、治療 の場におくべき状態にあることを想定し た。

この場合の特別学級とは、治療教育学級をさしてい る。しかし、現在はその様な施設が学校体制の中にな いので、治療的な接し方と配慮が行き届いた精薄特殊 学級でもやむを得ないと考觉ている。

（5）総合観察表に打活る各項目間の比較検討

- Table 2 -

この表は、39名の回答が、それぞれの項目にぞの 上うに分有しているかを百分比で表わしたものであ る。

例えば「末なざし」の項でい郎ば(1)のもの10人、 (2)15人、(3)11人、(4) 3 人が釷価した。この5ち(1) と(2)即ち普通学級で適応が可能であると想定した人 数を総数 39 人に対寸る百分比を求めると、 $67.5 \%$ と なった。 
こうした結果「就学への與味」「排泄」「身体の 発達」の項は比較的状態が良く、「友人関係」「多 動性」「予测性」が低かった。

自閉症児の就学に際し、「入学することへの関心」 と「排泄の自立」が重要な条件となっている。入学 への関心が強い子どもは、入学後の適灾を早めてい るし、排泄は担任教们の負担を軽くしていくためで ある。したがって、これらの項目については、比較 的良い状態を示しているのは当然である。

（6）指導の難易度別分布 - Table $3-$

前述した百分比に扮いて、状態の良い項目と悪い 項目を抽出し、更化整理しやすいように10項目を選 び、検討を加えた。をた項目の選定にあたっては、 教育現場の経験を加味したものである。

「侯担の程度」によって以上の項目を大別したも のが、Table 3 である。

1. 学年別にみると、「大へえ負担を感じている」 のは 2 年生以下で（ 3 年生が 1 名いるが）自閉症 児は 3 年生以上になると適応が良好になり、目担 も少なくなるという今までの研究と一致した。

2. 評洒点で 4 がなく、1 1 と 2 評洒が全体の $60 \%$ 以上を占めていれば、普通学級汇扣いて就学を継 続する可能性がある。

3. No. 41, 39, 43, の児童と No. 23, No. 3 の 児童の評価を比べると、負担度・適応度との開連 に扣いて一致しない。これは、担任教師の负担度 や子どもの適応度を客観的に把握することが困難 であることを表わしている。これは担任教師の経 験・資質、理解、熱意等による差であるう。

(7) 担任評侕之負担度 - 適応度 - 就学等の関係 - Table 4 -.
以上述べてきたものを整理し、評価設階で 1 と 2 の多い項から順に並べ、更に負担度、適応度、就学 させたことの可否を一覽表にしたものである。

若干のバラッキは認めながらす、評洒段階で、1 と 2 の計が全体の60\%以上あれば、普通学級で適応 していける可能性が見出された。しかし、今後の研 究として、No. 3. 21. 49. 41. 39.43 等の子ども について、バラッキが起きた原因を遍及していきた Wo

\section{$\mathrm{V}$ 今後の課題}

(1) 自閉症巟教育診断に関する考察を教育評価基準 ・ 就学判別基準を中心にすすめてきたが、就学後不適 応状態が長期にわたり継続している症例と、比較的 短期に好転する症例との間にいかなる差異があるか についての分析を行うまで至らなかった。

自閉症巟が好転する要因を明らかにすることによ って、指導諳画や指尊方法を確立していき、治療教 育学的体系をたてる努力をしていく必要がある。

（2）自閉症児の就学の可否については、治療機関に拉 いても十分な検討をしているのであるが、必ずしも 就学前の予測と就学後の状態は一致していなった。 このことについての原因を探り、就学判別基準の精 度を高めたい。

（3）教育措置については、国及び地方公共団体が長期 総合計画をたて、行政的財政的に白閉症児の受け入 れ体制を確立させる必要がある。またこのためには 教育、心理、医学の各野の協力が望まれる。

(4)この点で実験的に自閉症巟のための治療教育学級 や観察学級を設置していくことは、現実的な解決方 法の第一歩である。 
一 Table 1 - 総 合 観 察 表

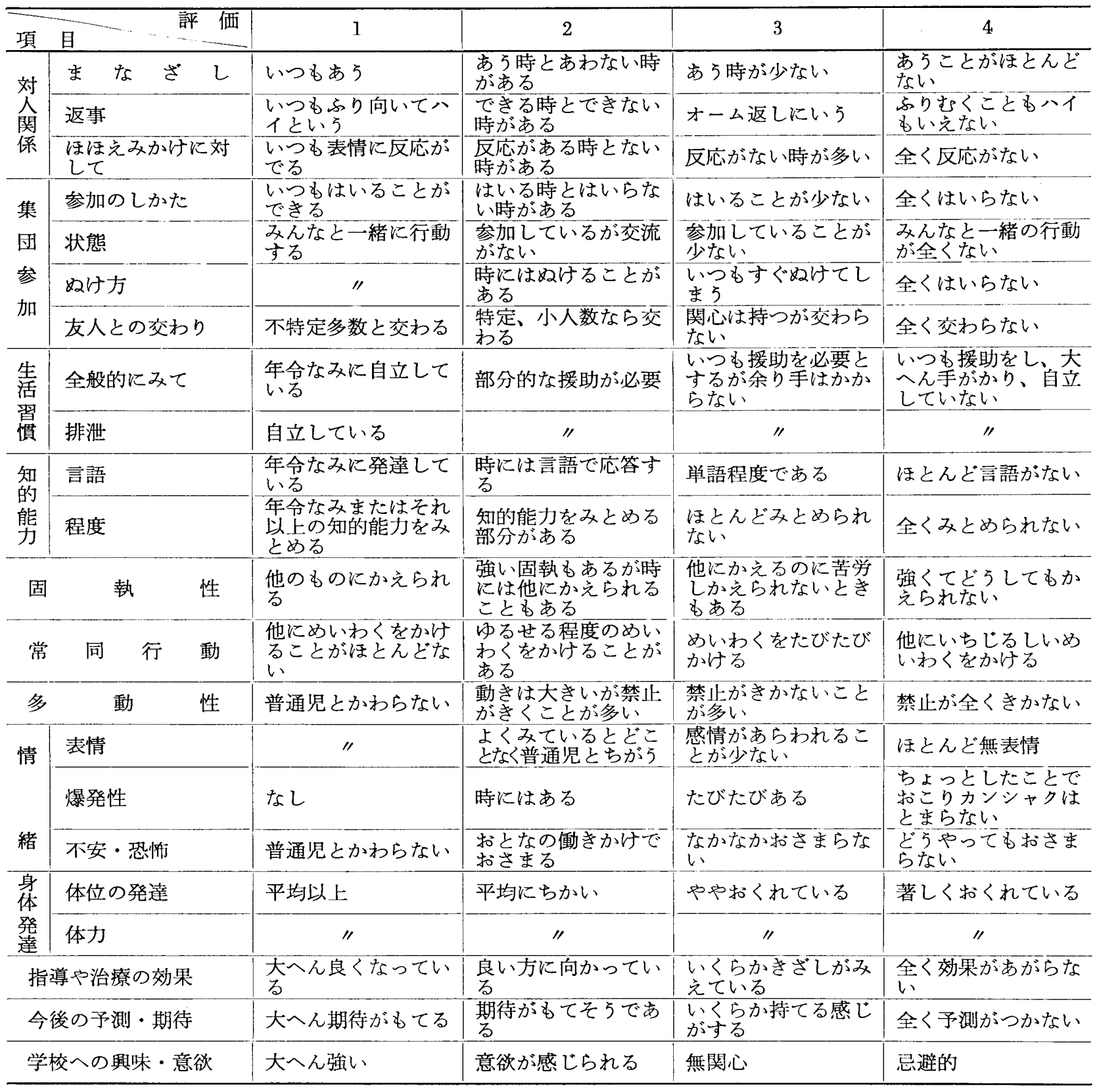

$\bigcirc$ 担任の感想

\begin{tabular}{|c|c|c|c|c|}
\hline 現在の適応状況 & 大へん良い & $\begin{array}{l}\text { ほ洼適応していると } \\
\text { みてよい }\end{array}$ & $\begin{array}{l}\text { 余り良いとはいえな } \\
\text { い }\end{array}$ & 全くわるい \\
\hline 指導の難易度 & $\begin{array}{l}\text { 普通児と同じ扱いで } \\
\text { よい }\end{array}$ & 全り負担にならない & $\begin{array}{l}\text { 常時指導と援助が必 } \\
\text { 要だが余り魵担では } \\
\text { ない }\end{array}$ & 大へん負担である \\
\hline 他児童への影響 & 注とんど困らない & $\begin{array}{l}\text { 時には困ることもあ } \\
\text { る }\end{array}$ & たびたび困る & $\begin{array}{l}\text { いつも大へん困って } \\
\text { いる }\end{array}$ \\
\hline 就学したことは & 就学させてよかった & \multicolumn{2}{|l|}{ なんともいえない } & 就学は無理であった \\
\hline
\end{tabular}


一 Table 2 - 総合観察表に扣ける各項目間の比較

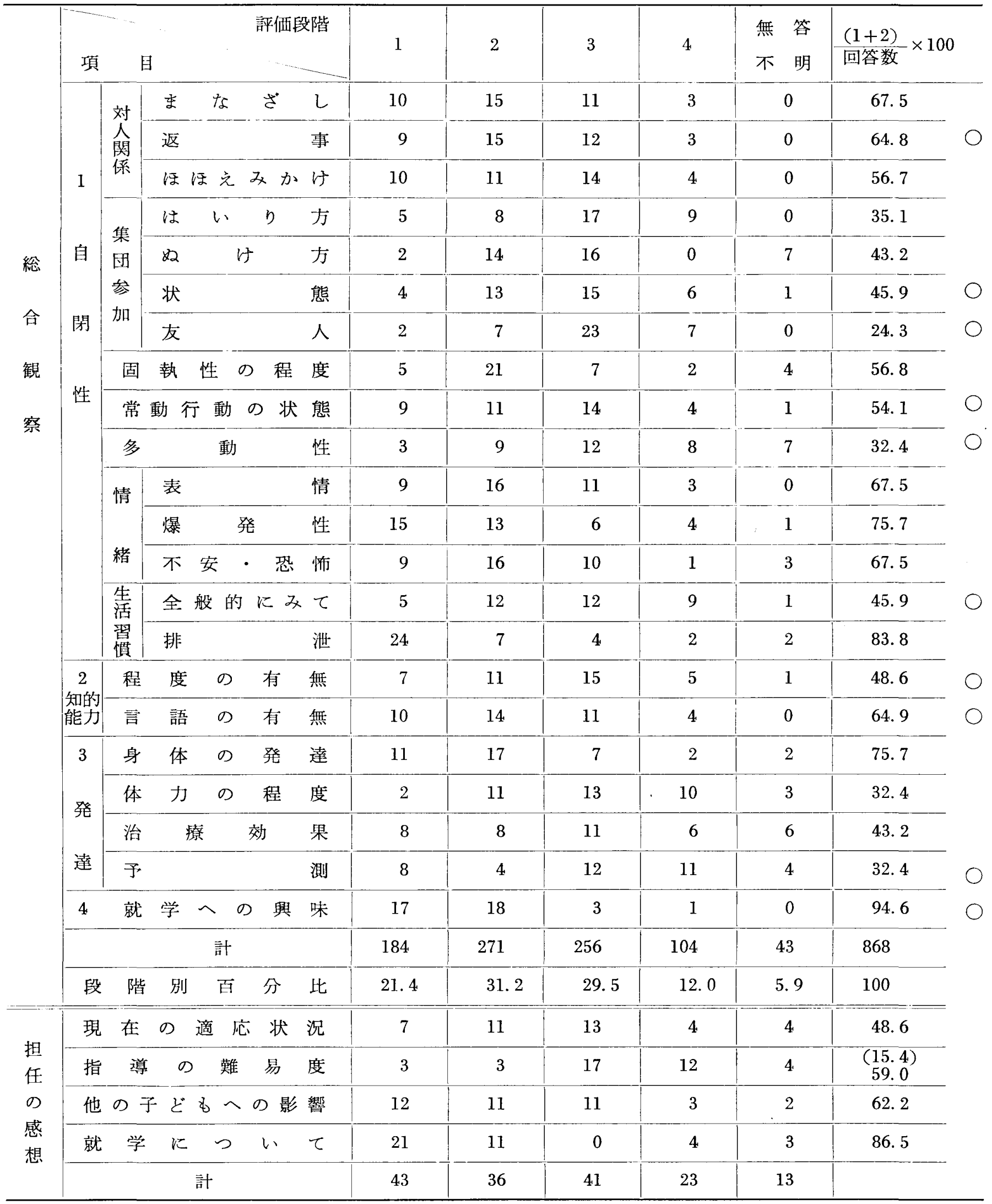

○印は Table 3，4 でとりあげた項目 
- Table 3- 指 導 - 難 易 度別分布

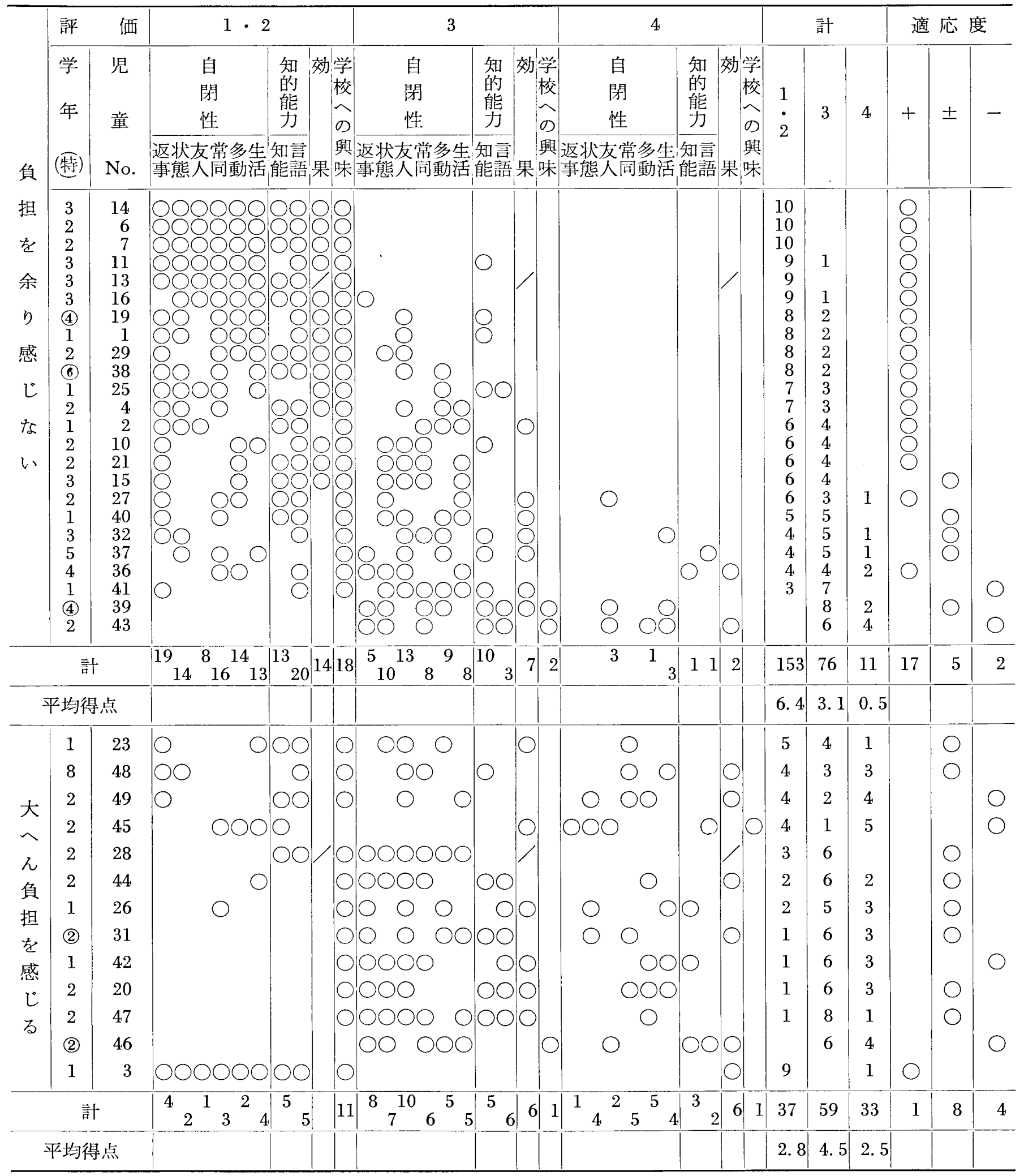


- Table 4 - 担任評価と負担度 ・適応度・就学等の関係

\begin{tabular}{|c|c|c|c|c|c|c|c|c|c|c|c|c|c|}
\hline \multirow{2}{*}{$\begin{array}{l}\text { 学 } \\
\text { 年 } \\
\text { (特) }\end{array}$} & \multirow{2}{*}{ 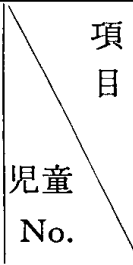 } & \multicolumn{3}{|c|}{ 評 価 段 階 } & \multicolumn{3}{|c|}{ 負 担 度 } & \multicolumn{2}{|c|}{ 適 応 } & 度 & \multicolumn{3}{|c|}{ 就学について } \\
\hline & & $\begin{array}{l}1 \\
\dot{2} \\
2\end{array}$ & 3 & 4 & $\begin{array}{l}\text { 軽 } \\
\text { い }\end{array}$ & $\begin{array}{c}\text { W担あ } \\
\text { でま } \\
\text { はり } \\
\text { な負 }\end{array}$ & $\begin{array}{l}\text { 奋 } \\
\text { 堹 }\end{array}$ & + & \pm & - & $\begin{array}{l}\text { 良 } \\
\text { 足 } \\
己 \\
た\end{array}$ & 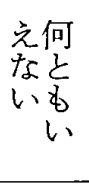 & $\begin{array}{c}\text { た無 } \\
\text { 理 } \\
\text { だ } \\
\text { つ }\end{array}$ \\
\hline 3 & 14 & $\cdot 10$ & & & 0 & & & 0 & & & 0 & & \\
\hline 2 & 6 & 10 & & & & $\bigcirc$ & & 0 & & & 0 & & \\
\hline 2 & 7 & 10 & & & & 0 & & 0 & & & 0 & & \\
\hline 3 & 11 & 9 & 1 & & 0 & & & 0 & & & 0 & & \\
\hline 3 & 13 & 9 & & & 0 & & & 0 & & & 0 & & \\
\hline 3 & 16 & 9 & 1 & & & $\bigcirc$ & & 0 & & & & $\bigcirc$ & \\
\hline 1 & 3 & 9 & & 1 & & & 0 & 0 & & & 0 & & \\
\hline (4) & 19 & 8 & 2 & & & 0 & & 0 & & & 0 & & \\
\hline 1 & 1 & 8 & 2 & & & 0 & & 0 & & & 0 & & \\
\hline 2 & 29 & 8 & 2 & & & 0 & & 0 & & & 0 & & \\
\hline (6) & 38 & 8 & 2 & & & 0 & & 0 & & & 0 & & \\
\hline 1 & 25 & 7 & 3 & & & 0 & & 0 & & & 0 & & \\
\hline 2 & 4 & 7 & 3 & & & 0 & & 0 & & & 0 & & \\
\hline 1 & 2 & 6 & 4 & & & 0 & & 0 & & & 0 & & \\
\hline 2 & 10 & 6 & 4 & & & 0 & & 0 & & & 0 & & \\
\hline 2 & 21 & 6 & 4 & & & 0 & & 0 & & & & $\bigcirc$ & \\
\hline 3 & 15 & 6 & 4 & & & 0 & & & 0 & & $\bigcirc$ & & \\
\hline 2 & 27 & 6 & 3 & 1 & & 0 & & 0 & & & $\bigcirc$ & & \\
\hline 1 & 40 & 5 & 5 & & & 0 & & & 0 & & & & \\
\hline 1 & 23 & 5 & 4 & 1 & & & 0 & & 0 & & & 0 & \\
\hline 3 & 32 & 4 & 5 & 1 & & 0 & & & $\bigcirc$ & & & 0 & \\
\hline 5 & 37 & 4 & 5 & 1 & & 0 & & & $\bigcirc$ & & & 0 & \\
\hline 4 & 36 & 4 & 4 & 2 & & 0 & & 0 & & & & 0 & \\
\hline 3 & 48 & 4 & 3 & 3 & & & 0 & & 0 & & & 0 & 0 \\
\hline 2 & 49 & 4 & 2 & 4 & & & 0 & & & 0 & & & \\
\hline 2 & 45 & 4 & 1 & 5 & & & 0 & & & 0 & 0 & $\bigcirc$ & \\
\hline 1 & 41 & 3 & 7 & & & 0 & & & & 0 & 0 & & \\
\hline 2 & 28 & 3 & 6 & & & & 0 & & $\bigcirc$ & & & & \\
\hline 2 & 44 & 2 & 6 & 2 & & & 0 & & 0 & & & 0 & \\
\hline 1 & 26 & 2 & 5 & 3 & & & 0 & & 0 & & & 0 & \\
\hline 2 & 47 & 1 & 8 & 1 & & & 0 & & 0 & & & 0 & \\
\hline (2) & 31 & 1 & 6 & 3 & & & 0 & & $\bigcirc$ & & & & 0 \\
\hline 1 & 42 & 1 & 6 & 3 & & & 0 & & & 0 & 0 & & \\
\hline 2 & 20 & 1 & 6 & 3 & & & 0 & & $\bigcirc$ & & & 0 & \\
\hline (4) & 39 & & 8 & 2 & & 0 & & & 0 & & 0 & & \\
\hline 2 & 43 & & 6 & 4 & & 0 & & & & 0 & & & 0 \\
\hline (2) & 46 & & 6 & 4 & & & 0 & & & 0 & & & $\bigcirc$ \\
\hline 計 & 37 & & & & 3 & 21 & 13 & 18 & 13 & 6 & 21 & 12 & 4 \\
\hline
\end{tabular}




\title{
EDUCATIONAL EVALUATION OF AUTISTIC CHILD
}

\author{
YASUTARO MURATA \\ Shibuya-ku Institute for Educational Research
}

We are now studying on the criteria which should be used when the school accepts the autistic child. In 1967 the teachers in Tokyo have teached 52 autistic children in their class; the eldest has been 11 years old the youngest 6 years old. All the children have had their own problems, varying in degree, and also the teachers have the great difficulties to teach them, because they have not easily responded to the teachers orders and carriculum and communicated to other children not good. But many autistic children have been adjusting to his class, because the school director and other teachers help the class-teacher very well; then the ratio of the adjusted autistic child is more increasing in 1968 than 1967, (We have established the Association of the Teachers for Emotionally-disturbeb-children in the same year.) In the classroom for normal child the autistic child adjusts better after third grade.

Out educational diagnosis for the autitic child:
(1) how can they adjust and learn in his class, (2) how can the teacher accepts him, (3) how can we evaluate the result of the teaching for hlm, have been established from the table which can estimate the grade of the adjustment of the autistic child by the entrance into a school and in a class, as follows :

(1) Status of the interest in a adult and a child, (2) Status of the participation to the group, (3) Development of the everyday-habits, (4) Grade of intelligence, (5) Presence of stereotyped behavior, (6) Presence of percistence, (7) Presence of hyperkinetic or hypokinetic behavior, (8) Presence of emotional outbursts, (9) Physical development, (10) Need for entrance into a school, (11) Effects of the treatment which has been judged from the staff of the institute, (12) Prognosis which the staff of the institute has presumed. 